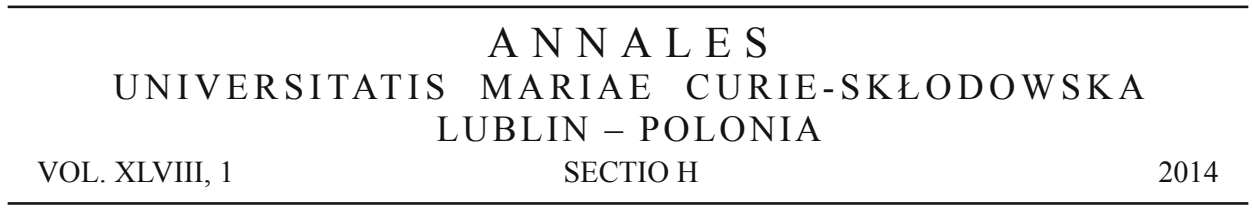

Uniwersytet Marii Curie-Skłodowskiej w Lublinie, Katedra Bankowości

JÓZEF ŁOBOCKI

Państwo a kapitat społeczny

The state and social capital

Słowa kluczowe: kapitał społeczny, państwo dobrobytu, prawo, społeczeństwo obywatelskie, wartości Keywords: social capital, welfare state, law, civil society, values

\title{
Wstęp
}

Bezpośrednią inspiracją do napisania artykułu było twierdzenie J. Graya, że we wszystkich nowoczesnych gospodarkach to państwo i rząd wykreowały instytucje rynkowe. Przy takim założeniu państwo staje się podmiotem generującym kapitał społeczny. J. Gray wydaje się nie zauważać, że to, co wcześniej funkcjonuje w gospodarce i społeczeństwie jako prawo zwyczajowe, państwo może jedynie usankcjonować (ustanowić jako prawo obowiązujące).

Celem artykułu jest zweryfikowanie poglądu o wpływie państwa na kapitał społeczny. Idealistyczna analiza relacji państwo-kapitał społeczny może rzeczywiście sugerować kapitałotwórczą funkcję tego pierwszego. Weryfikacja poglądu wymaga odpowiedzi przynajmniej na dwa podstawowe pytania: Czy państwo może tworzyć kapitał społeczny, tak jak na przykład tworzy kapitał ludzki? Jak państwo oddziałuje na istniejące zasoby kapitału społecznego? Uzyskanie odpowiedzi jest szczególnie ważne w związku z tym, że kapitał społeczny jest definiowany jako dobro publiczne. Jednocześnie badacze zwracają uwagę na fakt, że „nie ma mowy o tym, aby zwiększenie puli kapitału społecznego mogło być interesem jednostkowym” [Etzioni, 
s. 317-318]. Odpowiedzi na tak postawione pytania wymagają przeanalizowania, jak państwo może wpływać na tworzenie wartości i norm etycznych korzystnych dla funkcjonowania społeczeństwa i gospodarki. Natomiast przyjmując, że w społeczeństwie jest zgromadzony pewien zasób kapitału społecznego, należy dokonać oceny, jak realizowane programy rządowe wpływają na jego poziom.

\section{Kapitał społeczny}

Niejednoznaczność definicji kapitału społecznego funkcjonujących w poszczególnych dyscyplinach można tłumaczyć krótkim okresem obecności tego pojęcia w obiegu naukowym i publicystycznym. Natomiast fakt, że znajduje się ono w kręgu zainteresowania wielu dyscyplin, dodatkowo komplikuje możliwość uzgodnienia wspólnie akceptowanej definicji. Utrudnia to interdyscyplinarność dyskursu na temat całościowej koncepcji kapitału społecznego, co nie sprzyja dojściu do konsensusu w zakresie jego roli w społeczeństwie i gospodarce. $Z$ wielu występujących w literaturze definicji najbliższa jest mi ta podana przez F. Fukuyamę, który stwierdza: „Kapitał społeczny można najprościej zdefiniować jako zestaw nieformalnych wartości i norm etycznych wspólnych dla członków określonej grupy i umożliwiających im skuteczne współdziałanie" [Fukuyama, 2002, s. 156]. Uważam, że podkreślenie nieformalnego charakteru wartości i norm jako głównych desygnatów kapitału społecznego ma bardzo istotne znaczenie dla odróżnienia go od innych pojęć. Jednak w celu podkreślenia jego wymiaru ekonomicznego podaję własną definicję: kapitał społeczny są to nagromadzone w długim okresie korzystne efekty zewnętrzne interakcji społecznych i ekonomicznych w postaci nieformalnych wartości i norm etycznych. Tak rozumiane korzyści zinternalizowane przez społeczności stają się ich aktywami, a użyte z innymi zasobami powodują powstanie efektu synergii [Łobocki, 2013 s. 10].

Generalnie w literaturze przedmiotu panuje zgodność co do korzystnego wpływu kapitału społecznego na społeczeństwo i na gospodarkę, nie przeszkadza to jednak wielu badaczom doszukiwać się jego negatywnego oddziaływania w pewnych sytuacjach. W tym wypadku reprezentuję pogląd, że instytucja określana jako aktywa, majątek, zasób czy dobro nie może mieć negatywnego wpływu, a opisywane sytuacje nie mogą mieć negatywnych skutków. Obserwowane patologie społeczne są w rzeczywistości wynikiem braku kapitału społecznego. Liczna grupa badaczy, głównie socjologów, twierdzi, że zasoby kapitału społecznego można powiększać poprzez inwestowanie w niego. Ze względu na brak konkretnych przykładów ponoszenia kosztów lub nakładów, w których wyniku zasób kapitału społecznego by się zwiększał, uważam, że nie ma możliwości inwestowania w kapitał ludzki. Natomiast wielu badaczy wskazuje kapitał społeczny jako efekt zewnętrzny interakcji społecznych i ekonomicznych. Kapitał społeczny, tak jak inne efekty zewnętrzne, nie ma ceny, a jednocześnie ma wartość, gdyż jest produktywny. 


\section{Państwo dobrobytu}

Gdyby spojrzeć na państwo tak, jak je postrzegał D. Hobbes, czyli jako na bezstronnego suwerena, to jego rola w powiększaniu kapitału społecznego byłaby rzeczywiście bardzo duża [Hobbes, 1954, s. 297 i nast.]. Ten idealistyczny model nie sprawdzał się wcześniej i nie sprawdza się obecnie. Analiza empirycznych zachowań przeczy tezie o odgrywaniu przez państwo roli bezstronnego arbitra. J. Gray stwierdza: „Ekspansja państwa stała się prowadzoną na wielką skalę polityczną walką o środki” [Gray, 1995, s. 46]. Hobbesowskie państwo, które miało być rozjemcą, w praktyce stało się graczem zarządzającym ogromnymi środkami, o które konkuruje duża liczba bardzo różnych innych graczy. Nawet jeśli nie pominąć kwestię efektywności wykorzystania środków publicznych, to już sam podział przy wykorzystaniu instytucji rent seeking budzi uzasadnione wątpliwości.

Pojęcie rent seeking do literatury ekonomicznej wprowadziła A. Kruger w 1974 roku [Kruger, 1974, s. 291-303]. Na zjawisko to składają się działania osób fizycznych i prawnych, zarówno formalne, jak i nieformalne, ukierunkowane na uzyskanie korzyści materialnych w wyniku wywierania wpływu na instytucje publiczne odpowiedzialne za redystrybucję lub regulacje prawne. Zainteresowane podmioty angażują własne środki w celu zapewnienia sobie korzystnych rozstrzygnięć [Sztaba, 2002, s. 7]. Jest to przejaw marnotrawstwa w gospodarce, gdyż zaangażowane zasoby nie powodują powstania nowej wartości, a tylko przesunięcia pomiędzy beneficjentami. O ile można znaleźć uzasadnienie dla renty ekonomicznej, o tyle w przypadku renty politycznej nakłady są w całości społeczną stratą.

Korzyści związane z aktywnym poszukiwaniem renty uzyskuje się głównie dwoma sposobami: legalnie (lobbing) i nielegalnie (korupcja). Różnica między nimi polega na tym, że ta pierwsza została usankcjonowana prawnie - de facto jest to zalegalizowana korupcja ${ }^{1}$. Korupcja to zjawisko wysoko negatywnie skorelowane z kapitałem społecznym. Reasumując, należy stwierdzić, że rozszerzenie funkcji redystrybucyjnych państwa $\mathrm{i} /$ lub nadmierna regulacja prawna blokuje gospodarkę i niszczy kapitał społeczny.

Państwo jest strukturą hierarchiczną, która z definicji opiera się na przymusie, rozbudowując go i unowocześniając, co pociąga za sobą lawinowy wzrost wydatków. Sama struktura hierarchiczna do swojego funkcjonowania nie wymaga kapitału społecznego.

W jednym z wywiadów twórca komunitaryzmu A. Etzioni następująco opisuje rolę państwa: „W zatomizowanym społeczeństwie bogatego Zachodu pomiędzy biurokracją państwa opiekuńczego a jego jednostkami zieje pustką, w którą wdziera się rząd - aspiruje do roli obrońców interesu jednostek albo opiekuna »upośledzonych«”. A. Etzioni przestrzega, że stąd już tylko krok do „łagodnego despotyzmu rządu demokratycznego" [Etzioni, 2011].

\footnotetext{
${ }^{1}$ Przy Komisji Europejskiej w Brukseli oficjalnie jest akredytowanych ponad 6 tys. lobbystów.
} 
Również J.M. Buchanan bardzo krytycznie ocenia wpływ państwa na społeczeństwo: ,[...] względny rozrost sektora publicznego po II wojnie światowej przyczynił się do erozji standardów moralnych, czyniąc model »anarchii moralnej « $\ll^{2}$ modelem coraz częściej używanym do opisu społecznej interakcji” [Buchanan i inni, 2005, s. 167]. Autor bardzo krytycznie ocenia nadmierny rozrost sektora publicznego i obwinia go za większość negatywnych postaw moralnych, przejawiających się w zachowaniach zarówno prywatnych, jak i publicznych. Rozbudowany sektor zasiłków i państwowej opieki, jaki istnieje w rozwiniętych krajach Zachodu, jest skutkiem nieprzestrzegania zasad ekonomiki przez pół wieku, gdy trwała polityczna konfrontacja systemów. Wprowadzenie odpowiednich zmian instytucjonalno-konstytucyjnych zmierzających do zmniejszenia sektora publicznego pozwoliłoby wygenerować większą wartość ekonomiczną. Równie istotnym skutkiem byłyby zmiany postaw moralno-etycznych. Swoją ocenę konieczności zredukowania nadmiernie rozbudowanego systemu socjalnego J.M. Buchanan podsumowuje następująco: „W tym momencie etyka i ekonomika łączą się w jedną całość" [Buchanan i inni, 2005, s. 173].

Licznych przykładów negatywnego wpływu państwa dobrobytu na społeczeństwo amerykańskie i jednocześnie sposobów na przezwyciężenie nawarstwionych problemów dostarcza rzadko cytowana w polskiej literaturze książka D. Osborne’a i T. Gaeblera Rządzić inaczej [Osborne, Gaebler, 1992]. Autorzy za zaistniałą sytuację obwiniają politykę socjalną USA, zwłaszcza prowadzoną w drugiej połowie $\mathrm{XX}$ wieku. Dokładnie ta sama perspektywa czasowa posłużyła R. Putnamowi do analizy zmniejszających się zasobów kapitału społecznego Amerykanów, zawartej w książce Samotna gra w kręgle [Putnam, 2002]. Skojarzenie tych dwóch faktów po pierwsze, rozrostu państwa dobrobytu i po drugie, jednoczesnego ubytku kapitału społecznego - nie pozostawia wątpliwości co do negatywnego wpływu państwa na zasób kapitału społecznego.

\section{Prawo}

Istnieje poważne niebezpieczeństwo przeceniania roli państwa i prawa w procesie kreacji kapitału społecznego, czego dowodem jest poniższy cytat z artykułu J. Graya zamieszczonego w Filozofii liberalizmu: „Teoria Hayeka [...] sugeruje, że instytucje rynkowe powstają jako nieplanowany skutek działań ludzkich. [...] instytucje rynkowe we wszystkich nowoczesnych gospodarkach powstały nie w ten sposób, lecz zostały wykreowane przez prawo i rząd" [Gray, 1993, s. 31]. Jest to podstawowy błąd, gdyż prawo stanowione to forma kodyfikacji lub inkorporacji prawa zwycza-

\footnotetext{
2 Skonstruowany przez J.M. Buchanana model „,anarchii moralnej” opisuje pogoń za wąsko zdefiniowanym i oportunistycznym interesem własnym przez całe społeczeństwo lub większość biorących udział w interakcji społecznej. W modelu tym ludzie traktują innych jako część świata przyrody i nie okazują szacunku innym ani nie doznają go od innych.
} 
jowego właściwie w przypadku wszystkich istotnych instytucji rynkowych. Prawo zwyczajowe nie ma pochodzenia instytucjonalnego, ale stanowi wynik historycznego procesu ewolucji danej instytucji, której dotyczy. Na wcześniejszych etapach historii było prawem niepisanym i przekazywanym ustnie. Niemal wszystkie aktualnie funkcjonujące instytucje rynkowe kiedyś nie miały skodyfikowanej formy. Dotyczy to również współcześnie wprowadzanych do praktyki gospodarczej instytucji rynkowych. Obecnie obserwujemy w Polsce bardzo wydajną „,fabrykę prawa”, produkującą kiepskiej jakości artefakty prawne.

Konsekwencje toku rozumowania J. Graya można znaleźć w ważnej dla teorii kapitału społecznego polskiej literaturze - u A. Matysiaka (Źródta kapitału społecznego) i M. Gajowiak (Kapitat społeczny. Przypadek polski), w których autorzy, powołując się na wyżej cytowany pogląd J. Graya, traktują państwo i prawo jako najważniejsze źródła kapitału społecznego [Matysiak, 2002, s. 31; Gajowiak, 2012, s. 45]. A. Matysiak zakłada możliwość substytucji brakującego zaufania w kulturze indywidualistycznej instytucjami prawnymi [Matysiak, 2002, s. 61], jednak w innym miejscu swojej książki stwierdza: „W niczym nie umniejszając roli prawa w stosunkach między ludźmi, trzeba powiedzieć, że jest to instytucja bardzo kosztowna w zastosowaniu" [Matysiak, 2002, s. 58].

Jako przykład instytucji dotychczas funkcjonującej bez regulacji prawnych, a sięgającej swoim rodowodem czasów starożytnych można podać „hawalę” - system szybkich przekazów pieniężnych, również międzynarodowych, realizowanych bez jakiejkolwiek dokumentacji. Hawala, w języku hindi znana również jako hundi, oznacza „zaufanie”. System ten opiera się wyłącznie na zaufaniu i codziennie pozwala setkom tysięcy niezamożnych ludzi pracujących w różnych częściach globu przesyłać rodzinom pieniądze na drugi kraniec świata - tanio i bardzo szybko. Czyż nie jest to dowód na potęgę kapitału społecznego? Z drugiej zaś strony istnieje zhierarchizowany system bankowy działający na podstawie precyzyjnego prawa stanowionego przez państwo, który światową gospodarkę potrafi doprowadzić do wielkiego kryzysu, a swoich klientów do utraty całego zgromadzonego majątku [Dembinski, 2011; Łobocki, 2012].

Jak zatem dochodzi do powstania norm prawnych? Zdaniem F. Fukuyamy „relacje społeczne nie są naturalne; są środkami do osiągnięcia celów, których jednostka nie potrafi osiągnąć w izolacji. [...] relacje społeczne rodzą się tam, gdzie racjonalne dążenia jednostek wymagają współdziałania z innymi ludźmi” [Fukuyama, 1997, s. 323]. Powtarzające się relacje prowadzą do ukształtowania się w społeczeństwie określonych systemów. F.A. Hayek dodaje: „Prawa wywodzą się z systemów relacji” [Hayek, 2004, s. 228]. Autor Zgubnej pychy rozumu stawia warunek: „Relacje pomiędzy jednostkami mogą istnieć jedynie jako rezultat ich woli” [Hayek, 2004, s. 228].

\footnotetext{
${ }^{3}$ http://en.wikipedia.org/wiki/Hawala (dostęp: 10.10.2013). „As far as issues of culture identity and the need for close nit relationships to ensure survival go, it is no wonder that Hawala has become the preferred method of moving money around the »third « world".
} 


\section{Państwo a społeczeństwo obywatelskie}

Na długo przed upowszechnieniem się praktyk określanych jako państwo opiekuńcze francuski socjolog E. Durkheim zauważył znaczenie wszelkiego rodzaju wspólnot dla funkcjonowania państwa. „Narodem można efektywnie kierować jedynie wtedy, gdy między państwem a jednostkami istnieje wiele mniejszych grup wystarczająco bliskich jednostkom, by wciągnąć je w sferę swojego działania i tym sposobem przybliżyć do ogólnego nurtu życia społecznego" [Durkheim, 1933, s. 181-182]. Zmniejszająca się liczba tego typu grup oraz ich liczebność w społeczeństwie amerykańskim to, według R. Putnama, główne przejawy ubytku kapitału społecznego w tym kraju [Putnam, 2008].

J.M. Buchanan, mówiąc o swoich badaniach sfery publicznej, stwierdza, że w „badaniu etyki i ekonomii [...] formalne ograniczenia swobód zapisane w różnych dokumentach prawnych i w konstytucji nigdy nie wystarczają, aby zapewnić trwały porządek społeczny. Istotny jest również zestaw norm i standardów etycznych, mimo że przyznajmy, iż formalne i nieformalne ograniczenia stają się ich substytutami przy pewnych niewielkich korektach" [Buchanan, 2005, s. 27].

Według F. Fukuyamy instytucje demokracji i kapitalizmu dla prawidłowego działania muszą współistnieć z określonymi wartościami kulturowymi. Stabilność i dostatek społeczeństwa postindustrialnego nie może opierać się jedynie na prawie, umowie i gospodarczym racjonalizmie, konieczne jest wzmocnienie powszechną akceptacją obopólności interesów, moralnym obowiązkiem służby społeczeństwu oraz zaufaniem. Autor mówi o wartościach opartych raczej na zaufaniu niż na chłodnej kalkulacji i określa je warunkiem sine qua non funkcjonowania systemu [Fukuyama, 1997, s. 21].

W związku z tym, że państwo stało się wielkim gestorem środków, o które wszyscy zabiegają - walcząc ze sobą - jest ono odpowiedzialne za walkę osłabiającą przede wszystkim społeczeństwo obywatelskie. Istnienie społeczeństwa obywatelskiego jest warunkiem poprawnego funkcjonowania państwa, tymczasem to właśnie państwo niszczy tę instytucję. Wpływ rozrastających się funkcji państwa na uwiąd społeczeństwa obywatelskiego został już wcześniej należycie opisany przez F.A. Hayeka [Hayek, 1996, s. 28]. Państwo, które miało zapewnić ład społeczny, sukcesywnie go burzy, gdyż doprowadza do walki grup interesu o państwowe środki.

J. Gray ocenia, że „rząd będzie najlepiej wypełniał swoje obowiązki nie poprzez dalszą rozbudowę rozpadającego się państwa opiekuńczego, ale poprzez demontowanie go i kierowanie środków na powrót do sfery prywatnej. Rząd o ograniczonych uprawnieniach zawsze będzie miał konkretne obowiązki, jeśli chodzi o zmniejszenie ubóstwa, wspieranie oświaty, opieki zdrowotnej oraz ochronę wartościowych tradycji kultury" [Gray, 1995, s. 21]. 


\section{Państwo jako kreator wartości}

Rola państwa w zakresie budowania kapitału społecznego jest bardzo odmiennie widziana w różnych teoriach. Jeśli przyjąć, że kapitał społeczny jest dobrem publicznym, to rzeczywiście na państwie spoczywa obowiązek jego dostarczania. Taki obowiązek na państwo „nakłada” T. Hobbes. Jednak J. Gray, który z pewnością przeceniał rolę państwa w kreowaniu instytucji gospodarki rynkowej, uważa, że pomimo istnienia takiego obowiązku i kolosalnego rozrostu swoich instytucji państwo nie wywiązuje się z niego. Według J. Graya współczesne państwo, zamiast dostarczać dobra publiczne - dostarcza prywatne. Obecnie państwo zaspokaja przede wszystkim prywatne preferencje zorganizowanych grup interesu [Gray, 1995, s. 45].

Noblista J.M. Buchanan, powołując się na F.A. Hayeka, również noblistę, i na jego koncepcję „wielkiego społeczeństwa”, stwierdza: „W ładzie moralnym ludzie nie traktują interesów innych jak swoich własnych (z wyjątkiem interesów członków najbliższej rodziny), ale zarazem nie traktują też innych jako wyrzutków moralnych [...] czyli jako części świata przyrody" [Buchanan i inni, 2005, s. 166-167]. Zdaniem autora inne osoby istnieją jako partnerzy do przeprowadzenia wzajemnie korzystnych interakcji, w tym również wymiennych. Relacje moralne charakteryzują się wzajemnym szacunkiem i tolerancją. Ludzie przestrzegają zasad, które umożliwiają jednakowe traktowanie wszystkich, w przeciwieństwie do oportunistycznego wykorzystania i dyskryminacji [Buchanan i inni, 2005, s. 167].

Nawiązując do pojęć używanych przez Hayeka, J.M. Buchanan stawia retoryczne pytanie o to, czy „ład moralny”, który jest uznawany za klasyczno-liberalny ideał, mógł zostać osiągnięty na początku XX wieku, czy też jego realizacja była realna dopiero pod koniec stulecia. Autor jednoznacznie stwierdza, że „kapitał społeczny, przejawiający się zarówno w normach zachowań, jak i w postawach społecznych, uległ bez wątpienia znacznej erozji w ciągu XX wieku" [Buchanan i inni, 2005, s. 167]. J.M. Buchanan widzi niezbędność równoległej realizacji transformacji instytucjonalnej, koniecznej do tworzenia bodźców do odnowy, i jednocześnie potrzebę odradzania ducha i poczucia wspólnego celu w społeczeństwie składającym się z wolnych obywateli.

Warto przytoczyć opinię jednego z bardziej znanych ekonomistów zajmujących się ekonomią sektora publicznego w Stanach Zjednoczonych, R.A. Musgrave'a, również laureata Nagrody Nobla, którego z pewnością nie można posądzić o poglądy liberalne. Stwierdza on, że „funkcją zasad jest zapewnienie ram ograniczających zachowania szkodliwe dla konstruktywnych interakcji jednostek w społeczeństwie, lecz funkcją zasad jest także umożliwienie zaistnienia, wywołanie takich konstruktywnych interakcji” [Buchanan i inni, 2005, s. 48].

Próbując odpowiedzieć pytanie o to, czy państwo może kreować kapitał społeczny, jeszcze raz przytoczę opinię F. Fukuyamy: „Rządy państw mają moc, by wdrażać politykę nakierowaną na wykorzystanie kapitału społecznego, ale ciągle sprawia im trudność poznanie sposobu na jego ponowne odbudowywanie" [Fukuyama, 1997, 
s. 21]. Analizując koncepcję kapitału społecznego w kontekście państwa, nie sposób nie zauważyć, że państwo zbyt często jest konsumentem kapitału społecznego, natomiast słabo wykorzystuje swoje możliwości tworzenia infrastruktury społecznej, w wyniku czego jego poziom mógłby wzrastać.

\section{Zakończenie}

Reasumując, jeśli przyjmiemy, że na kapitał społeczny składają się nieformalne wartości i normy etyczne, a państwo może tworzyć jedynie normy prawne, to w ten sposób otrzymamy negatywną odpowiedź na pierwsze pytanie postawione we wstępie. Natomiast państwo ma możliwości pośrednie - może poprzez budowę infrastruktury społecznej (edukacja, kultura, nauka, wymiar sprawiedliwości) korzystnie oddziaływać na budowanie kapitału społecznego. Obowiązkiem państwa jest tworzenie mechanizmów ochronnych, utrudniających zachowania oportunistyczne i sprzeczne nie tylko z prawem, ale i zasadami współżycia społecznego - dobrymi obyczajami. Jeśli prawo stanowione i system jego egzekwowania chroni zasady współżycia społecznego - poziom kapitału społecznego wzrasta, w przeciwnym wypadku następuje jego spadek.

Odpowiedzą na drugie pytanie - o kierunek oddziaływania państwa na istniejący zasób kapitału - są opinie cytowanych powyżej badaczy reprezentujących poglądy zarówno liberalne, jak i lewicowe. Autorzy ci jednoznacznie negatywnie oceniają wpływ realizowanych programów socjalnych na wartości i normy podzielane przez poszczególne społeczeństwa.

Szeroki zakres środków, jakimi dysponuje państwo, oraz znaczna swoboda w nakładaniu podatków sprawiają, że staje się ono konkurentem społeczeństwa obywatelskiego. Obecnie większość rządów, o ile nie wszystkie, odchodzi od koncepcji państwa ograniczonego. Konsekwencją tego jest deprecjacja nieformalnych wartości i norm niezbędnych do prawidłowego funkcjonowania demokracji i rynku.

\section{Bibliografia}

1. Buchanan J.M., Musgrave R.A. (2005), Finanse publiczne a wybór publiczny. Dwie odmienne wizje państwa, Wydawnictwo Sejmowe, Warszawa.

2. Dembinski P.H. (2011), Finanse po zawale. Od euforii finansowej do gospodarczego ładu, Wyd. Studio Emka, Warszawa.

3. Durkheim E. (1933), The Division of Labor in Society, Macmillan, Nowy Jork.

4. Etzioni A. (2011), Kupuj mniej, uwolnij się, „Gazeta Wyborcza” 24-26.12.

5. Fukuyama, F. (1997), Zaufanie. Kapitat spoteczny droga do dobrobytu, Wydawnictwo Naukowe PWN, Warszawa-Wrocław.

6. Fukuyama F. (2000), Wielki wstrząs, Bertelsmann Media Politeja, Warszawa. 
7. Fukuyama F. (2002), Kapitał społeczny, [w:] Kultura ma znaczenie. Jak wartości wpływaja na rozwój społeczeństw, Zysk i S-ka Wydawnictwo, Poznań.

8. Gajowiak M. (2012), Kapitat społeczny. Przypadek polski, PWE, Warszawa.

9. Gray J. (1993), Filozofia liberalizmu, Warszawa.

10. Gray J. (1995), O rzadzie ograniczonym, Centrum im. A. Smitha, Warszawa.

11. Hayek A.F. (1996), Droga do zniewolenia, Arcana, Kraków.

12. Hayek A.F. (2004), Zgubna pycha rozumu. O błędach socjalizmu, Arcana, Kraków.

13. Hobbes T. (1954), Lewiatan, czyli materia, forma i władza państwa kościelnego i świeckiego, Państwowe Wydawnictwo Naukowe, Warszawa.

14. http://en.wikipedia.org/wiki/Hawala.

15. Krueger A.O. (1974), The Political Economy of the Rent-Seeking Society, "The American Economic Review", 64 (3).

16. Łobocki J. (2012), Sektor finansowy a kapitat społeczny, [w:] Ekonomia, J. Sokołowski, M. Rękas, G. Węgrzyn (red.), Prace Naukowe Uniwersytetu Wrocławskiego, nr 245.

17. Łobocki J. (2013), Kapitat społeczny jako korzystny efekt zewnętrzny interakcji społecznych i ekonomicznych, [w:] Współczesne problemy ekonomiczne. Globalizacja. Liberalizacja. Etyka, Zeszyty Naukowe Uniwersytetu Szczecińskiego, z. 7.

18. Matysiak A. (1999), Źródła kapitału społecznego, Wydawnictwo Akademii Ekonomicznej we Wrocławiu, Wrocław.

19. Osborne D., Gaebler T. (1992), Rządzić inaczej. Jak duch przedsiębiorczości przenika i przekształca administracje publiczna, Media Rodzina, Poznań.

20. Putnam R. (2008), Samotna gra w kręgle. Upadek i odrodzenie wspólnot lokalnych w Stanach Zjednoczonych, Wydawnictwa Akademickie i Profesjonalne, Warszawa.

21. Sztaba S. (2002), Aktywne poszukiwanie renty. Teoria, przykłady historyczne. Przejawy w polskiej gospodarce lat dziewięćdziesiątych, Szkoła Główna Handlowa, Warszawa.

\section{The state and social capital}

The problems associated with social capital require, due to their relevance and short history, that this institution be compared with the environment in the broad sense. The state and law are without doubt institutions whose functioning is determined by social capital but the state can only indirectly influence the level of social capital through creating social infrastructure. When adopting a definition of social capital as the external beneficial results of social and economic interactions in the form of informal values and ethical norms, we do not take the state into account in this definition. The institution of civil society allows us to understand the relationship between social capital and the state (and law). 